\title{
Monika Strzępka i Paweł Demirski - Bonnie i Clyde polskiego teatru
}

DOI: http://dx.doi.org/10.12775/LC.2018.020

Streszczenie: Monika Strzępka i Paweł Demirski to obecnie jeden z najważniejszych duetów teatralnych w Polsce. Artyści są znani z zaangażowanych wypowiedzi i spektakli krytykujących ekonomiczne i polityczne podstawy neoliberalizmu, a także konsekwentnie dekonstruujących mity polskości. Ich twórczość wpłynęla na charakter rodzimego teatru politycznego. Artykuł omawia kierunki artystycznych poszukiwań, interesujące twórców tematy i estetykę spektakli.

Słowa kluczowe: Monika Strzępka, Paweł Demirski, najnowszy teatr polski, teatr polityczny, sztuka zaangażowana

\section{Monika Strzępka and Paweł Demirski - Bonnie and Clyde of the Polish theatre}

\begin{abstract}
Monika Strzępka and Paweł Demirski are one of the most important theatrical duos in Poland. The artists are known for their engaged statements and performances consistently deconstructing the myths of Polishness, criticizing the economic and political foundations of neoliberalism. Their work influenced the character of the political theater in Poland. The article discusses the directions of Strzępka and Demirski artistic searches, themes and the aesthetics of theirs performances.
\end{abstract}

Keywords: Monika Strzępka, Paweł Demirski, contemporary Polish theatre, political theatre, socially-engaged art

* Adiunkt w Zakładzie Dramatu i Teatru Instytutu Nauk o Kulturze i Studiów Interdyscyplinarnych Uniwersytetu Śląskiego w Katowicach. Zainteresowania badawcze: estetyczne przemiany w teatrze i dramacie XX i XXI wieku, społeczne praktyki performatywne, krytyka i eseistyka teatralna, instytucjonalne podstawy działalności teatralnej. E-mail: a-glowacka@o2.pl. 
onika Strzępka i Paweł Demirski to niekwestionowane gwiazdy współczesnego polskiego teatru, przez kilka lat $\mathrm{z}$ powodzeniem wyznaczające kurs teatru krytycznego, społecznie i politycznie zaangażowanego. Na tle twórców debiutujących na początku XXI wieku wyróżniali się nie tylko radykalizmem stawianych tez i antyestetycznym językiem scenicznym, budowanym na kontrze do tego, co było akceptowane w tzw. mieszczańskim teatrze, ale również - wyrazistym medialnym wizerunkiem antysystemowych artystów, stawiających siebie w opozycji wobec dominującego porządku społecznego, politycznego i artystycznego. Potyczki z otaczającą rzeczywistością i zbiorową tożsamością, budowaną wokół wspólnych mitów czy ideologii, w ostatnich latach stały się mniej radykalne, jednak nie mniej dotkliwe w diagnozowaniu rzeczywistości i punktowaniu miejsc zapalnych. Wydaje się, że złagodzeniu uległa również forma ich spektakli, choć może po prostu ich teatralne pismo przeszło proces konwencjonalizacji.

Ten reżysersko-dramatopisarski duet współpracuje ze sobą od 2007 roku, czyli od pierwszej wspólnej premiery - spektaklu Dziady. Ekshumacja (Teatr Polski we Wrocławiu), chociaż nie było to ich pierwsze spotkanie. Poznali się w Teatrze Wybrzeże w Gdańsku, gdy jego dyrektorem był Maciej Nowak (2000-2006). Demirski był wówczas kierownikiem literackim (2003-2006), zaangażowanym m.in. w swój autorski projekt „Szybki Teatr Miejski” - serię spektakli opierających się na autentycznych historiach, granych w prywatnych mieszkaniach na terenie Gdańska. Z kolei Strzępka dostała szansę wyreżyserowania na gdańskiej scenie swojego drugiego spektaklu: Yorick, czyli spowiedź błazna (2005), który był pastiszem dzieł Williama Szekspira autorstwa Andrzeja Żurowskiego, utrzymanym w konwencji stand-upu komentującego współczesną rzeczywistość.

Wrocławska reinterpretacja Dziadów Adama Mickiewicza zaproponowana przez duet wzbudziła sporo kontrowersji, ale też zapowiedziała główne kierunki ich artystycznych poszukiwań: podważanie i rozmontowywanie narodowych mitów, oddawanie głosu wykluczonym czy eksponowanie narracji dotychczas nieobecnych w sztuce i w przestrzeni publicznej, jak chociażby chłopskie pochodzenie dużej części polskiego społeczeństwa czy dyskurs postpamięciowy dotyczący przeszłości często instrumentalizowanej przez ideologiczne przekazy. Kolejne spektakle wnosiły ponadto krytykę ekonomicznego i politycznego neoliberalizmu oraz tropienie konsekwencji wolnego rynku dla życia społecznego. Ich znakiem rozpoznawczym stały się obecna w twórczości świadomość polityczna i klasowa oraz stawianie siebie w opozycji do liberalnych elit. Niedawno, w rozmowie opublikowanej w „Dialogu” dramatopisarz wprost przyznał, że całe jego „dorosłe, świadome politycznie życie było sprzeciwem wobec Unii Wolności” (Demirski 2018).

Do tej pory duet zrealizował ponad dwadzieścia wspólnych spektakli, w tym projekt teatru w odcinkach. Są również twórcami serialu Artyści, emitowanego jesienią 2016 roku w polskiej telewizji. Akcja toczy się w teatrze, a kolejne odcinki odsłaniają kulisy tworzenia sztuki w Polsce w publicznych instytucjach: ich dyrektorzy, chcąc zrealizować artystyczny repertuar, stale muszą lawirować między wymaganiami zaproszonych do współpracy twórców, oczekiwaniami polityków i niekompetencją urzędników odpowiedzialnych za kulturę. Warto również wspomnieć, że ich sposób pracy w stałym zespole reżysersko-dramatugicznym (wzorowany na teatrach niemieckich) był jednym z pierwszych w Polsce i - jak się okazuje - jednym z nielicznych, które przetrwały próbę czasu w pierwotnym składzie. 
Zaangażowane wypowiedzi i antysystemowe spektakle upominające się o prawa przeciętnych obywateli, krytykujące polityczny i artystyczny establishment w opinii niektórych recenzentów od razu uczyniły z nich spadkobierców „lewackiego spisku”, ale też dość szybko zostały zauważone i wykorzystane przez media. Wizerunek niepokornego artysty, buntownika okazał się niezwykle atrakcyjny medialnie, zwłaszcza że szedł w parze z sukcesem artystycznym. Strzępkę i Demirskiego zaczęto określać jako „wściekły tandem”, „Bonnie i Clyde polskiego teatru” czy „terrorystów-komunistów” (Drewniak 2010: 46; Węgrzyniak 2008), co wzmacniali sami artyści, żywiołowo reagując zarówno na dziennikarskie prowokacje, jak i na realne zdarzenia, które Strzępka komentowała w mediach społecznościowych. Swoją rolę artysty określili już na początku kariery. W rozmowie z Joanną Derkaczew, przeprowadzonej dla „Gazety Wyborczej” w 2008 roku, Strzępka oceniała, że

oderwanie od rzeczywistości nie jest tylko problemem artystów, ale też całej polskiej inteligencji. Obraz Polski widziany z Warszawy czy kilku innych dużych miast jest niepełny i zafałszowany. Większość elit nie domyśla się nawet, z kim współzamieszkuje polskie terytorium (Strzępka, Demirski 2008).

Konsekwentnie w kolejnych spektaklach prowadzili narrację z perspektywy prowincji i grup marginalizowanych, a ostrze krytyki wymierzone przeciwko dominującej władzy dotykało również środowisk uprzywilejowanych ${ }^{1}$.

Bohaterami spektaklu Diamenty to węgiel, który wziąt się do roboty (Teatr Dramatyczny im. Jerzego Szaniawskiego w Wałbrzychu, 2008) na podstawie Wujaszka Wani Antona Czechowa uczynili współczesnych mieszkańców prowincji, którzy nie skorzystali na transformacji ustrojowej. Ludzie ci pogrążeni w marazmie i depresji zapijali alkoholem marzenia o lepszym życiu w stolicy. Artyści, koncentrując uwagę na jednostkach, którym się nie powiodło, ujawniali nieprzystawalność ówczesnej neoliberalnej retoryki o „braniu swojego życia w swoje ręce" do społecznej i ekonomicznej kondycji tzw. ofiar transformacji. Nie bez znaczenia było również miejsce powstania tej inscenizacji. Wałbrzych do dzisiaj jest synonimem prowincji, która wiele straciła na przemianach ekonomicznych. Z kolei w spektaklu Opera gospodarcza dla ładnych pań i zamożnych panów (Teatr im. Jana Kochanowskiego w Opolu, 2008) na podstawie Opery za trzy grosze Bertolta Brechta twórcy krytykowali współczesny system pomocy charytatywnej, który często sprowadza się do zarabiania pieniędzy. Wykazywali jego nieskuteczność, sugerując, że w obecnym kształcie jest raczej producentem ofiar. Wreszcie przedstawienie Wimię Jakuba S. (Teatr Dramatyczny im. Gustawa Holoubka w Warszawie, 2011) dotykało tabuizowanego w Polsce tematu chłopskich korzeni większości polskiego społeczeństwa² . Przywołując postać Jakuba Szeli, przywódcy rabacji galicyjskiej, która miała charakter antypańszczyźniany i antyszlachecki, artyści rekonstruowali genealogię współczesnych podziałów klasowych. Jeden $\mathrm{z}$ wątków przedstawienia dotyczył uwikłania Polaków w system kredytowy, który zdaniem autorów spektaklu jest dzisiejszą wersją pańszczyzny.

\footnotetext{
1 Wspominam o tym w artykule Głowacka 2015. Fragmenty tego artykułu wykorzystałam w prezentowanym tekście.

2 Spektakl był prezentowany w 2012 roku w ramach 21. Międzynarodowego Festiwalu Teatralnego "Kontakt” w Toruniu.
} 


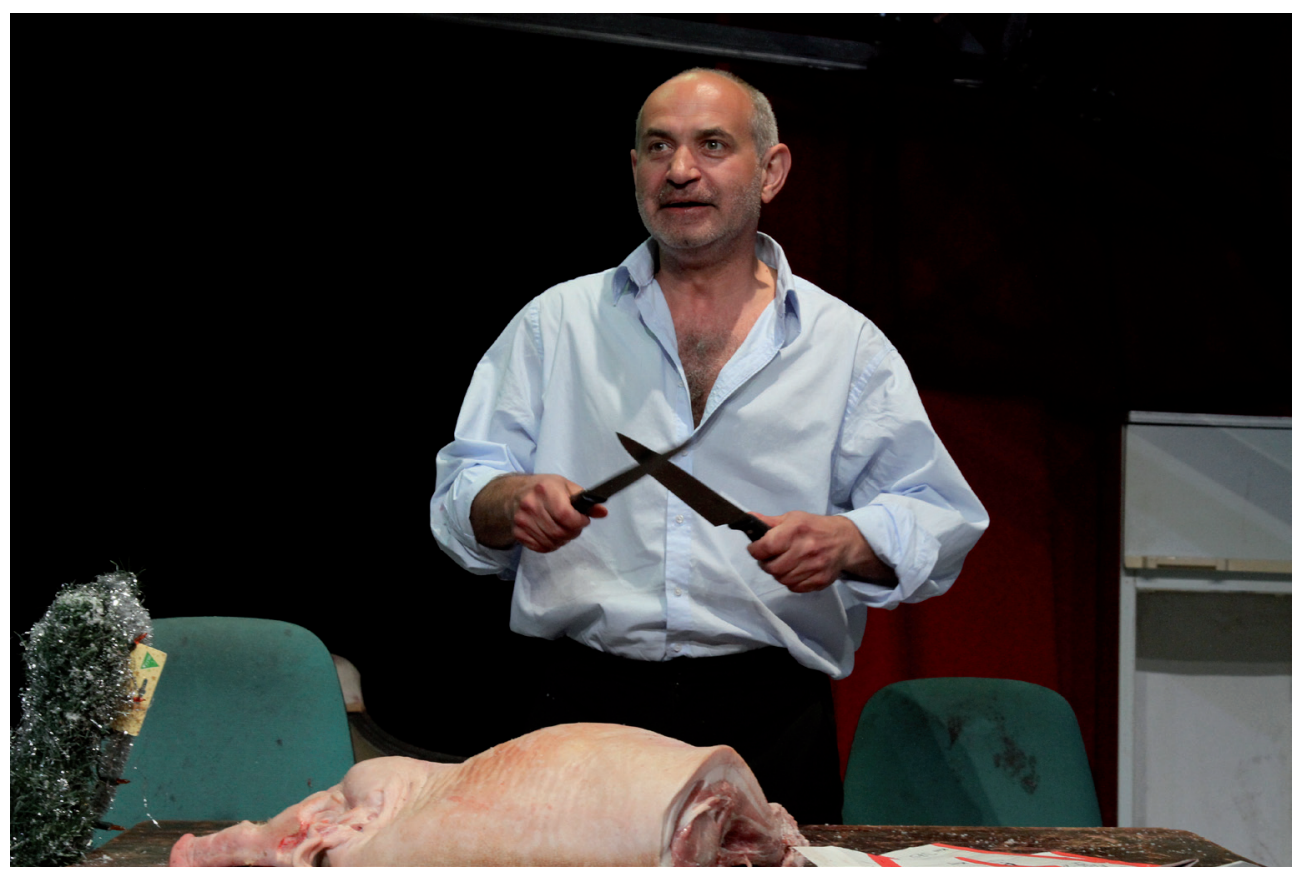

Krzysztof Dracz w roli głównej w spektaklu W imię Jakuba S. Moniki Strzępki i Pawła Demirskiego

Fot. Magdalena Kujawa

Wybór strategii artystycznej duetu dość szybko został dostrzeżony i doceniony. To właśnie za radykalizm artystyczno-polityczny: „odwagę”, „sprzeciw wobec sytemu” i „ducha walki”, zostali nagrodzeni trzy lata po wspólnym debiucie przez jury 3. Międzynarodowego Festiwalu Teatralnego „Boska Komedia” w Krakowie (2010). Jury, składające się z producentów i kuratorów teatralnych, doceniło spektakl Był sobie Andrzej Andrzej Andrzej i Andrzej (Teatr Dramatyczny im. Jerzego Szaniawskiego w Wałbrzychu, 2010), którym artyści rozliczali polskie elity polityczne i artystyczne z zaniechań wobec grup zepchniętych na margines przez transformację ustrojową. „Boska Komedia” rozpoczęła również dobrą passę duetu. Już miesiąc później, w styczniu 2011 roku, otrzymali Paszport „Polityki”. Nominujący doceniali Demirskiego za „bezkompromisowy sposób wprowadzenia na polskie sceny dyskursu postpamięciowego", a Strzępkę za formę sceniczną, która doskonale służy przełożeniu tych tekstów na scenę (Anna R. Burzyńska). Chwalono ich za konsekwentnie rozwijany projekt teatralny, w którym „rozmontowuje się oficjalne i potoczne, mocne definicje narodowej wspólnoty, tożsamości, zbiorowej pamięci” (Marcin Kościelniak). Wreszcie „za głos w imieniu wszystkich wykluczonych” (Jacek Cieślak) (Teatr 2010). W uzasadnieniu werdyktu podkreślano, że prestiżowe wyróżnienie otrzymali za zaangażowanie społeczne i rozwijaną przez nich formę teatru krytycznego, a także wypracowany język sceniczny: „żywiołową teatralność łamiącą bariery dobrego smaku na rzecz dobrego myślenia”3.

\footnotetext{
3 Cyt. pochodzi z uzasadnienia przyznania nagrody, wygłoszonego przez Anetę Kyzioł (krytyczkę teatralną oraz szefową działu kultury w „Polityce”).
} 
Kolejne nagrody oznaczały wejście do teatralnego mainstreamu, co u niektórych komentatorów rodziło obawę porzucenia przez artystów lewicowych ideałów i osłabienie wywrotowego potencjału ich sztuki. Paszporty „Polityki” wzbudziły sporo emocji przede wszystkim dlatego, że duet stale podkreślał swoją antysystemowość i niechęć do elit, a nagroda przyznawana przez ten tygodnik w pewnym sensie artystyczne elity wyłania. Strzępkę i Demirskiego zaczęto z nominacji rozliczać. Twórcy - wbrew przeróżnym spekulacjom i prognozom - nagrodę odebrali, nie odmówili sobie jednak wykonania swoistego performansu rozmontowującego konwencję oficjalnej gali: Strzępka nie dostosowała się do dress code'u uroczystości, zaś Demirski zaproponował minutę ciszy nad polską kulturą. Wywołało to oczywiście konsternację na widowni, ale i wpisało się w konsekwentnie przez nich performowany wizerunek artystów-buntowników (zob. Papuczys 2013). Co ciekawe i nieczęste w wypadku artystów teatralnych, nawet garderoba laureatki: dżinsowe spodnie i bluza od dresu, jeszcze przez kilka dni była komentowana na różnych plotkarskich portalach.

Strzępka i Demirski w zasadzie od pierwszego wspólnego spektaklu teatr traktują jako miejsce, gdzie dyskutuje się na drażliwe tematy, poddaje analizie mechanizmy władzy, wątpi w bezkrytycznie przyjmowane sądy i podważa teorie, które wydają się oczywiste. Wśród poruszanych przez duet zagadnień pojawiają się zatem bieżące problemy polityczne, społeczne i gospodarcze: kryzys publicznej służby zdrowia i kryzys rodzicielstwa (Położnice szpitala św. Zofii, 2011), polityka przemysłu żywieniowego (Bierzcie i jedzcie, Teatr Rozrywki w Chorzowie, 2013), patologie w funkcjonowaniu spółek skarbu państwa (Firma, Teatr Nowy im. Tadeusza Łomnickiego w Poznaniu, 2012), konsekwencje urynkowienia sztuki (O dobru, Teatr Dramatyczny im. Jerzego Szaniawskiego w Wałbrzychu, 2012, Courtney Love, Teatr Polski we Wrocławiu, 2012) czy arogancja władzy wzmacniana brakiem społeczeństwa obywatelskiego (Tęczowa Trybuna 2012, 2011). Wydaje się, że nie ma tematów, które byłyby dla nich artystycznie nieciekawe lub zbyt ryzykowne. W duchu teatru epickiego świadomie wpisują swoje realizacje w konwencję społecznej debaty - wszystkie części spektaklu w odcinkach Klątwa: odcinki z czasu beznadziei (Teatr Łaźnia Nowa w Krakowie, 2014) zadają właściwie to samo pytanie: o stan demokracji i przyszłość Polski. Identyczne pytanie pojawia się również $\mathrm{w}$ jednym $\mathrm{z}$ ostatnich przedstawień, czyli $K$. (Teatr Polski w Poznaniu, 2017), w którym rysują obraz Polski pod rządami Kaczyńskiego. Spektakl jest wyrazem obywatelskiej bezradności i rozczarowania polską klasą polityczną. Nie przynosi rozwiązań, które - wcielone w życie - pozwolą lepiej myśleć o przyszłości. Artyści raczej sugerują brak perspektyw, stawiając diagnozę, że jako społeczeństwo nie potrafimy uwolnić się od obecnego politycznego impasu.

Interesuje ich sztuka, która jest zakotwiczona w rzeczywistości społecznej i działa na rzecz realnej zmiany. „To chyba nie jest najgorzej, że teatr wychodzi z własnego elitarnego podwórka. Mnie by bardzo cieszyło, gdybym o naszym spektaklu przeczytała w dziale »społeczeństwo «, a nie tylko w dziale »recenzje «" - mówiła Strzępka w rozmowie dla „Gazety Wyborczej” (Strzępka 2011). W zasadzie od początku współpracy celowo wprowadzają do swoich spektakli postaci, wydarzenia i zjawiska z przestrzeni publicznej, które poddają krytycznemu namysłowi. Już w spektaklu Byt sobie Polak Polak Polak i diabet czyli w heroicznych walkach narodu polskiego wszystkie sztachety zostaty zużyte z 2007 roku (Teatr Dramatyczny im. Jerzego Szaniawskiego w Wałbrzychu) pojawiły się postacie jednoznacznie identyfikowane przez widzów i krytykę z arcybiskupem Juliuszem Paetzem czy 


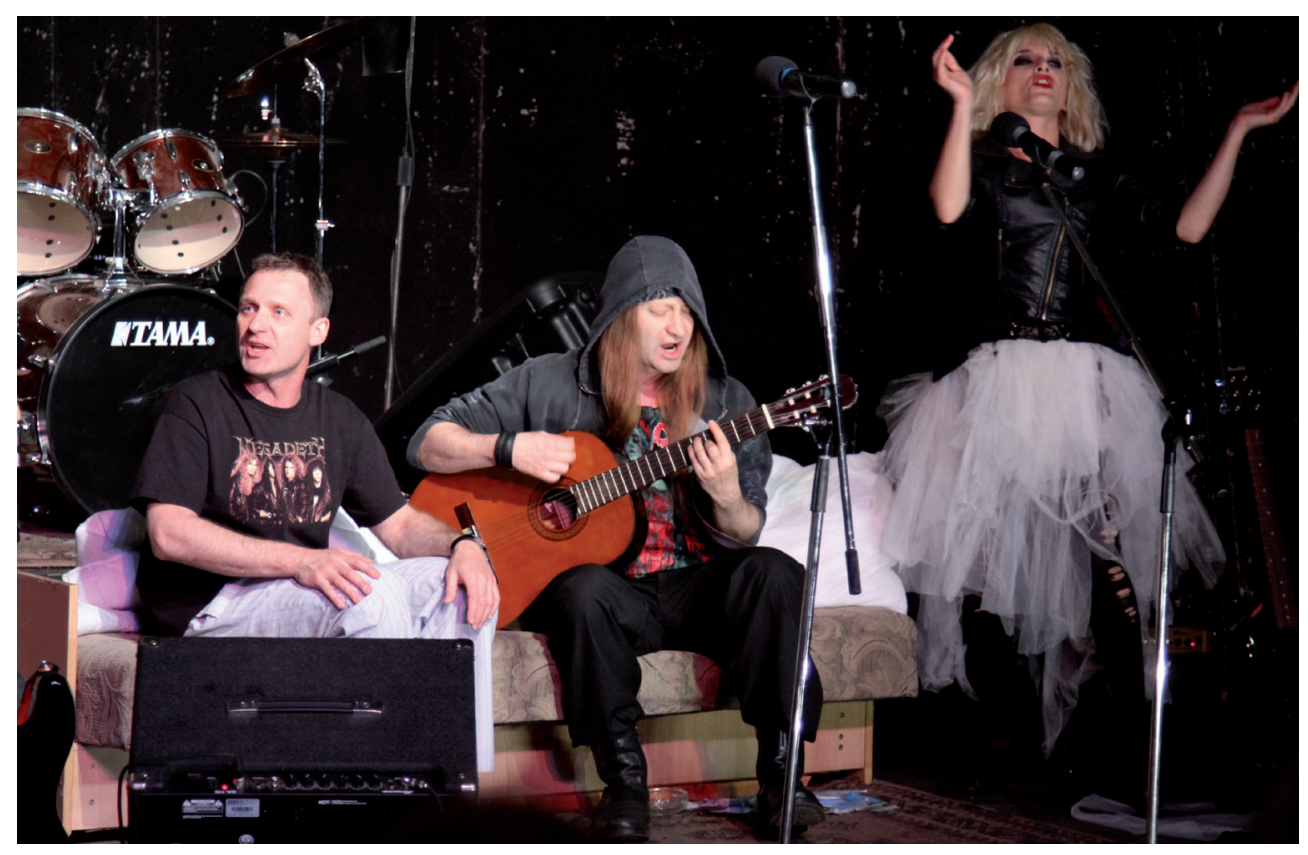

Courtney Love w reżyserii Moniki Strzępki

Fot. Magdalena Kujawa

Wojciechem Jaruzelskim. We wspomnianym Byt sobie Andrzej Andrzej Andrzej i Andrzej przedstawicielami krytykowanych elit uczynili Andrzeja Wajdę, Kazimierza Kutza, Krystynę Jandę i Leszka Balcerowicza. W Tęczowej Trybunie jedną z postaci była pani prezydent Hania, oderwana od rzeczywistości społecznej, nieświadoma potrzeb i oczekiwań wyborców, która była karykaturą prezydent Warszawy, Hanny Gronkiewicz-Waltz, ostro wówczas krytykowanej przez aktywistów ruchów miejskich. W tym samym spektaklu krytyczne aluzje do teatru Krzysztofa Warlikowskiego złożyły się na zarzut, że tworząc spektakle dotyczące mniejszości seksualnych, nie podjął działań emancypacyjnych na płaszczyźnie społecznej. Wreszcie w K. głównymi protagonistami uczynili Donalda Tuska i Jarosława Kaczyńskiego, skrzętnie unikając realistycznego odwzorowania na scenie prezesa Prawa i Sprawiedliwości. Pojawiający się na początku spektaklu mężczyzna „bez żadnego trybu”, w kaszkiecie, mówiący o swoim niskim wzroście i w charakterystyczny sposób sepleniący, był zaledwie stand-upową parodią kontrowersyjnego polityka. Tym samym twórcy sugerowali, że właściwy prezes nie jest tu, gdzie myślimy, choć chcielibyśmy go sprowadzić do komicznej figury. Postrzeganie Kaczyńskiego jedynie przez pryzmat jego niefortunnych wypowiedzi i niezdarnych zachowań fałszuje jego prawdziwy obraz, odbiera mu znaczenie, mimo że jest to niebezpieczny, bezwzględny gracz.

Galerię postaci zaczerpniętych z przestrzeni publicznej zasilają w spektaklach duetu nie tylko politycy i osoby publiczne, ale również artyści. Bohaterka spektaklu O dobru, Amy Winehouse, stała się symbolem artysty przeżutego i zniszczonego przez przemysł muzyczny. Na prace nad tym przedstawieniem wpłynął zainicjowany przez Strzępkę i Demirskiego ruch protestacyjny „Teatr nie jest produktem/Widz nie jest klientem”, wymierzony w klasę polityczną w obronie teatru artystycznego. W jego finale twórcy zawarli nawet wiarę w możliwość zjednoczenia się społeczeństwa w obronie wspólnych interesów i wartości: 
zgromadzeni wokół ogniska widzowie i aktorzy śpiewali hymn kibiców drużyny piłkarskiej z Liverpoolu You'll Never Walk Alone, tworząc rodzaj teatralnej wspólnoty, co jednak - jak pokazały dalsze losy tej inicjatywy - okazało się utopią ${ }^{4}$. Do tematu wspólnoty duet powrócił w 2016 roku, realizując w Narodowym Starym Teatrze w Krakowie Triumf woli. Mimo iż tytuł sztuki nawiązywał do filmu Leni Riefenstahl, nie miał wiele wspólnego z twórczością kontrowersyjnej artystki. Raczej odczarowywał ów tytuł kojarzący się z nazistowską propagandą, a celem, jaki postawili sobie twórcy, było przekonanie widzów o konieczności wspólnego działania w imię społecznej solidarności. Zwieńczeniem wywodów na ten temat była ostatnia scena, która odwoływała się do wydarzeń w Wielkiej Brytanii z czasów Margaret Thatcher, gdy walijskich górników z likwidowanych wówczas kopalni wspierali londyńscy geje i londyńskie lesbijki. Kończąca spektakl piosenka Billy’ego Bragga There is Power in the Union w wykonaniu aktorów podkreślała siłę ludzkiej jedności, co - jak się okazało - było bardzo potrzebne entuzjastycznie reagującej publiczności.

Równie istotny jak krytyczny komentarz do aktualnych zjawisk społecznych, politycznych i ekonomicznych jest w twórczości Strzępki i Demirskiego nurt rozliczeniowy. W wydaniu duetu oznacza podważanie i rozmontowywanie dominujących narracji (również historiozoficznych) na rzecz historii indywidualnych czy dekonstruowanie tożsamościowych mitów i sposobów ich ujmowania. We wspomnianych na początku Dziadach. Ekshumacji rozprawiali się z mitem heroicznego Polaka i narodową pamięcią, wykorzystywaną wówczas w polityce historycznej przez rządzącą partię Prawo i Sprawiedliwość. Wizerunek żolnierza walczącego za „wolność waszą i naszą”, traktowany jako jeden z fundamentów narodowej tożsamości, został zderzony z obrazem wojny, o którym mało kto chce pamiętać. Znalazły się w nim ofiary żydowskich pogromów, przesiedleń i obozów. Narodową pamięć zapełnili uczestnicy Praskiej Wiosny, studenci nękani przez aparat komunistycznej represji i opozycjoniści prześladowani przez reżimową władzę. Zamiast chlubnej przeszłości twórcy przygotowali inwentarz win i popełnionych zbrodni.

Pamięć o wojnie, która ma charakter przede wszystkim społeczny - a najczęściej jest instrumentalizowana i wykorzystywana przez dominującą władzę do kształtowania określonej wizji świata - stała się tematem dwóch kolejnych inscenizacji: Sztuki dla dziecka (Teatr im. Cypriana Kamila Norwida w Jeleniej Górze, 2009), analizującej pamięć o Holokauście w postnazistowskiej Europie, oraz spektaklu Niech żyje wojna!!! (Teatr Dramatyczny im. Jerzego Szaniawskiego w Wałbrzychu, 2009) inspirowanego niezwykle popularnym w Polsce filmem i książką Janusza Przymanowskiego Czterej pancerni i pies. Wykorzystując tę powszechnie znaną opowieść, Strzępka pokazała, że wojna w jednostkowym odbiorze jest odrażająca i cielesna, w przeciwieństwie do tej wzniosłej i heroicznej pokazanej w książkach czy filmach. Ten wątek powrócił ponownie w przygotowanym przez reżyserkę Koncercie Galowym Przeglądu Piosenki Aktorskiej we Wrocławiu Proszę państwa, będzie wojna (2015) oraz w spektaklu Bitwa warszawska 1920 (Narodowy Stary Teatr im. Heleny Modrzejewskiej w Krakowie, 2013). Krakowskie przedstawienie było w pewnym sensie również opowieścią o współczesności. Uczestnicy słynnego Cudu nad Wisłą, bitwy, która uratowała Zachód przed impetem armii bolszewickiej, zostali pokazani jako

\footnotetext{
${ }^{4}$ Mimo zaangażowania wielu osób, polegającego chociażby na odczytywaniu przed spektaklami w różnych miastach w Polsce listu do widzów alarmującego o trudnej sytuacji w kulturze, akcja nie przerodziła się w znaczący ruch społeczny, który miałby możliwość nacisku na polityków i urzędników decydujących o polityce kulturalnej państwa.
} 
ludzie pogrążeni w apatii. Artystka zestawiła ich z przywódcami antykomunistycznej opozycji, którzy przejęli w państwie władzę. Ich wizerunki wyświetlane na początku spektaklu sugerowały ocenę współczesnych elit politycznych, dotkniętych zdaniem twórców również genem inercji, objawiającym się brakiem pomysłu na przyszłość kraju, który w 1989 roku odzyskał niepodległość.

Demitologizacja przeszłości, podobnie jak w twórczości Jana Klaty, w spektaklach duetu oznaczała zwykle wyciąganie na wierzch narodowych kompleksów i eksponowanie ignorowanych albo wręcz spychanych w nieświadomość tematów. W spektaklu Był sobie Polak Polak Polak i diabet, czyli w heroicznych walkach narodu polskiego wszystkie sztachety zostaty zużyte patos teatru mówiącego o ważnych narodowych sprawach reżyserka zastąpiła przekazem utrzymanym w konwencji kabaretu, w którym pojawiły się stereotypowe, karykaturalne wizerunki Polaków: była więźniarka z Auschwitz, chłopka, dresiarz, opuszczony przez rodziców chłopak z depresją, biskup pedofil i generał w ciemnych okularach. Jak mantra powracały opowieści o ukrywanych zbrodniach z czasów wojny, traumy po stanie wojennym, kompleksy polskiego prowincjonalizmu i resentymenty wobec Ziem Odzyskanych. Refleksje na temat polskiego antysemityzmu, który zdaniem twórców miał charakter klasowy, powróciły w przedstawieniu nie-boska komedia. Wszystko powiem Bogu! (Narodowy Stary Teatr im. Heleny Modrzejewskiej w Krakowie, 2014) na podstawie NieBoskiej komedii Zygmunta Krasińskiego, a później w spektaklu Marzec '68. Dobrze żyjcie - to najlepsza zemsta (Teatr Żydowski w Warszawie, 2016). W warszawskim przedstawieniu pobrzmiewały rozczarowanie teatrem i polityką oraz świadomość, że nie ma ucieczki od zbiorowej pamięci, jakakolwiek by ona nie była. Oba spektakle w porównaniu z wcześniejszymi inscenizacjami okazały się zaskakująco wyciszone, utrzymane w melancholijnym nastroju, tak jakby artyści szukali dla siebie nowego języka.

Rozmontowując rozmaite dyskursy władzy sterujące życiem indywidualnym i zbiorowym, twórcy wprowadzają w przedstawienia również odwołania do własnego życia i obecności w sferze publicznej. Tym samym sugerują, że krytyki stosunków społecznych dokonują z pozycji przeciętnego obywatela, z którym widz może się utożsamić. Pracując nad Położnicami szpitala św. Zofii, zdradzili, że do powstania spektaklu zachęciły ich własne przeżycia związane z przyjściem na świat ich dziecka (Strzępka, Demirski 2011). W spektaklu Courtney Love ${ }^{5}$ autobiograficzny akcent zaznaczyli w postaciach pary artystów, którzy wreszcie dotarli na zawodowy szczyt. W czasie realizacji tej premiery mieli już za sobą spektakularne sukcesy i nagrody, można więc powiedzieć, że w wątku autobiograficznym było sporo ironii. Wreszcie w spektaklu $W$ imię Jakuba $S$., portretującym pokolenie współczesnych trzydziestokilkulatków zniewolonych kredytami, można ich rozpoznać w parze bohaterów, którzy zastanawiają się nad zaciągnięciem kredytu. Postać reprezentująca Strzępkę pojawia się w charakterystycznym dla reżyserki dresie, mówi o swoich wiejskich korzeniach, do których również reżyserka często się przyznaje, wreszcie wspomina o tworzonym z partnerem teatrze, który uczynił z nich najbardziej krytyczną parę polskiego teatru politycznego.

\footnotetext{
5 Spektakl prezentowany na MFT „Kontakt” 2014. Nagroda dla najlepszego aktora festiwalu: Mariusz Kiljan za role Axela Rose'a i Wychowawcy Kolonijnego.
} 


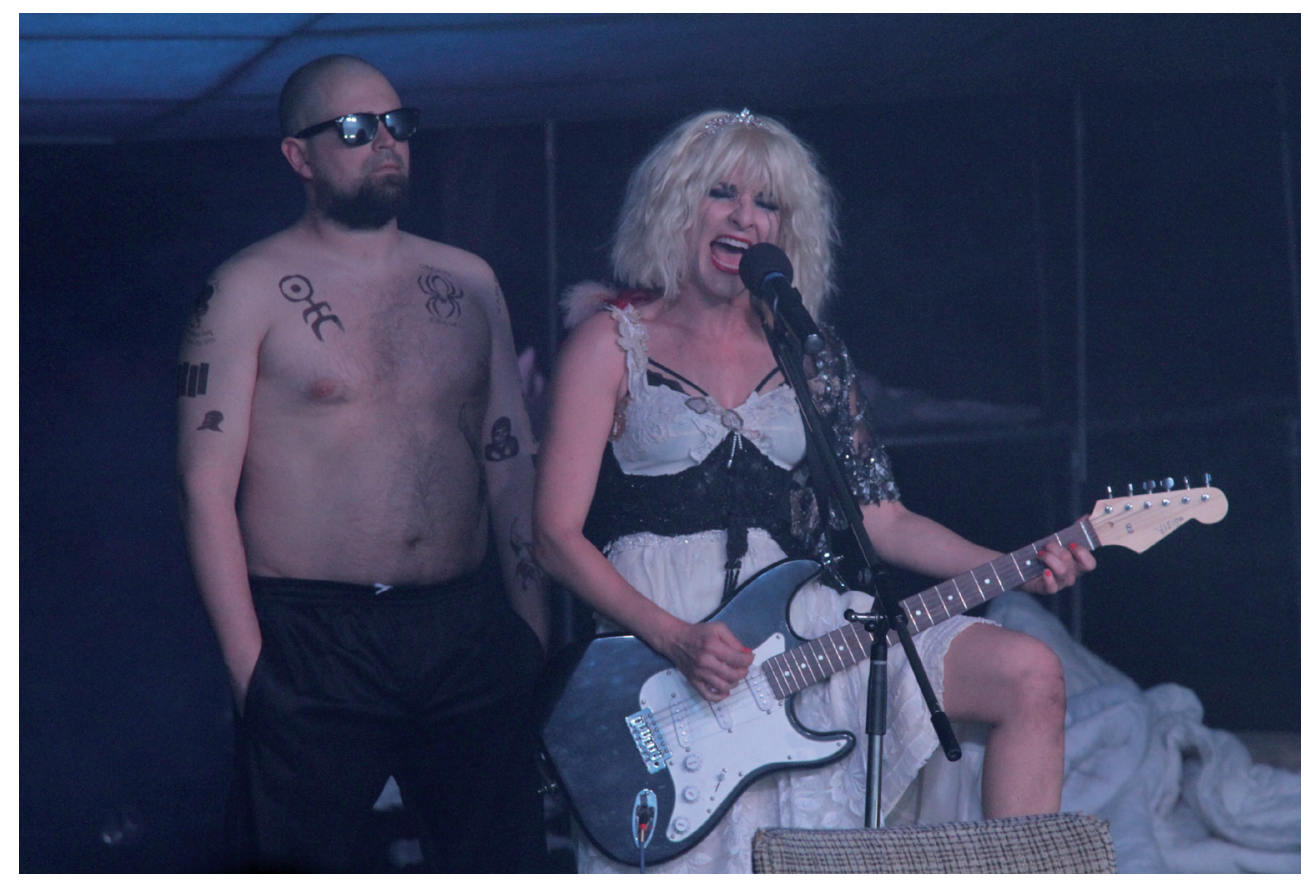

Katarzyna Strączek jako Courtney Love w spektaklu Moniki Strzępki

Fot. Magdalena Kujawa

Dziełem w szczególny sposób odwołującym się do ich doświadczeń jako artystów, a przy okazji demaskującym medialne mechanizmy przekształcające bunt $\mathrm{w}$ atrakcyjną formę dla odbiorców (ich wizerunek lewicowych buntowników często wykorzystywały media), był przygotowany w 2012 roku w Komunie//Warszawa autoironiczny performans re//mix Dario Fo przestat instrukcje. Występ ten - w jego tytule artyści przywołali nazwisko jednego ze swoich ulubionych lewicowych twórców - składał się z fragmentów, w których Paweł Demirski wcielał się w postać Dario Fo, i aktorskich etiud: mówiącej po śląsku Agnieszki Kwietniewskiej i Andrzeja Kłaka, w kostiumie papieża reprezentującego na scenie hierarchów kościelnych. W performansie Dario Fo/autor/performer/intelektualista próbował nawiązać kontakt z kobietą reprezentującą klasę robotniczą (Agnieszka Kwietniewska). Oczywiście strategia lewicowego artysty okazała się nieskuteczna, a język, którego używał, zamiast zbliżać, oddalał protagonistów od siebie. Refleksja Demirskiego zmierzała więc do gorzkiej konstatacji, że lewicowy teatr nie potrafi nawiązać kontaktu z publicznością nieinteligencką. Co z tego, że próbuje reprezentować jej interesy, skoro nie ma z nią wiele wspólnego. Podział społeczeństwa na wzajemnie nierozumiejące się obozy artysta uwypuklił zwłaszcza w finale performansu, zwracając się do publiczności z prośbą o interwencję w sprawie uwolnienia Piotra Staruchowicza „Starucha”. Przywódca kiboli Legii zdaniem prawicowych mediów był „więźniem sumienia” od kilku miesięcy bezprawnie przetrzymywanym w areszcie śledczym. Demirski zaproponował widzom podpisanie petycji w tej sprawie do ówczesnego premiera Donalda Tuska, co - jak łatwo przewidzieć nie spotkało się z entuzjastycznym przyjęciem osób przybyłych na lewicowy spektakl. Końcowa scena potwierdzała również oczywistą już dzisiaj prawdę, że ideowe i polityczne podziały, przynajmniej w Polsce, skutecznie blokują działanie we wspólnej sprawie. 
W wywiadach pojawiających się w różnych mediach twórcy otwarcie wskazują na lewicowe tradycje teatralne i artystyczne inspiracje istotne dla ich pracy. Są to zarówno wspomniany już Dario Fo z niepoprawnymi politycznie burleskami, jak i Frank Castorf konsekwentnie rozsadzający ramy konwencji teatralnych. Można również wymienić twórczość Rene Pollescha, chętnie zrywającego z iluzją teatralną, którego spektakle są komentującymi współczesność wypowiedziami politycznymi. Strzępka i Demirski podobnie kształtują formę i poetykę spektakli w duchu światopoglądowych deklaracji. Zwłaszcza na początku kariery artyści demonstracyjnie odżegnywali się od tradycji teatru wysokiego, elitarnego, skierowanego do publiczności, dla której był formą manifestacji społecznego prestiżu. Siebie sytuowali po stronie wielbicieli gatunków i form przez tę publiczność pogardzanych i odrzucanych. Na horyzoncie ich artystycznych zainteresowań znalazły się zatem farsa, burleska, rewia, kabaret czy musical, uchodzące za sztukę popularną, które w różnym stopniu inspirowały rozwiązania formalne w realizowanych spektaklach.

Nic dziwnego, że naruszając przyjęte kanony tematyczne i estetyczne, zwłaszcza na początku, byli oskarżani o brak szacunku dla tradycji (przepisanie Mickiewiczowskich Dziadów uznawano za profanację), nieznajomość konwencji (czego wyrazem były gatunkowe kolaże, łączenie wysokiego z niskim, patosu z kabaretowymi wstawkami i grubymi żartami - widzów spektaklu Bierzcie i jedzcie witała ze sceny rozpięta na szerokość okna scenicznego wielka pupa) czy ideologiczne zaangażowanie i publicystyczną doraźność. Ich przedstawienia, składające się z luźno powiązanych scen, epizodów i przejść, z jednej strony odsyłają do poetyki kabaretu, z drugiej - obecność cytatów i nawiązań do innych spektakli oraz tekstów kultury przypomina strukturę internetowej sieci. Poszczególne sekwencje inscenizacji łączą się ze sobą na zasadzie skojarzeń, jakkolwiek w całość wiąże je wpisana w spektakl wypowiedź światopoglądowa. Podobnie jak u Castorfa jest dostrzegalna skłonność duetu dramaturgiczno-reżyserskiego do naruszania reguł sztuki scenicznej. Przejawia się ona nie tylko $\mathrm{w}$ łączeniu gatunków i form oraz nielinearnej narracji, ale również w radykalnych zabiegach adaptatorskich, które w wypadku Demirskiego oznaczają przeróbkę dzieł wyjściowych, tak literackich (choćby Dziady, Opera za trzy grosze, Nie-Boska komedia), jak filmowych (Czterej pancerni i pies). Istotę poetyki dramaturga trafnie ujęła Joanna Krakowska:

Owszem, są tu cytaty, imiona bohaterów, motywy, sceny, pomysły fabularne - wszystko to jednak niemal za każdym razem podporządkowane jest nowej strukturze, przewrotnej stylistyce i autonomicznemu przekazowi, które jeśli mają coś wspólnego z pierwowzorem, to z całą pewnością na wspak (Krakowska 2011: 476).

Strzępka współpracując z kolejnymi scenografami, z premedytacją wprowadza na scenę antyestetykę, która jest rodzajem kulturowego wysypiska. Dekoracje są budowane z kartonowych ścian i pudeł (Opera gospodarcza, scenogr. Monika Strzępka), starych mebli (Diamenty to węgiel który wziąt się do roboty, scenogr. Dawid Załęski), zdezelowanych kinowych foteli (Byt sobie Andrzej..., scenogr. Michał Korchowiec), rozpadających się kanap i zniszczonych tapczanów albo krzeseł. Na scenie walają się snopki słomy (Bitwa warszawska 1920, scenogr. Michał Korchowiec), stopy aktorów oblepia piasek (Triumf woli, scengr. Martyna Solecka) albo ziemia (Byt sobie Polak..., scenogr. Marcin Mierzicki), kiedy indziej na scenie pojawia się zbiornik wodny, po którym brodzą unurzani po kostki bohate- 
rowie (Klątwa. Odcinki z czasu beznadziei, scenogr. Michał Korchowiec). Od ścian odchodzi tapeta albo warstwy farby, a trzaskające drzwi nie zawsze się domykają (Diamenty...). Rzeczywistość na scenie zostaje sprowadzona do roli miejskiego wysypiska, gdzie sztuczne rośliny: palmy, kaktusy i pnącza walczą o lepsze miejsce z całym cywilizacyjnym śmietnikiem: lodówkami, kanapami i plastikowymi przenośnymi toaletami (Śmierć podatnika, scenogr. Dawid Załęski).

Radykalne środki wyrazu, m.in. rwana narracja, krzyk, eksponowanie fizjologii na scenie - postaci ujawniają się w całej swojej cielesności, „bez uzasadnienia psychologicznego czy wewnętrznego przeżywania” (Wyznawcy 2008: 351) - estetyka inspirowana rozmaitymi odmianami kultury popularnej oraz podejmowanie tematów społecznie drażliwych, a przez teatr dotychczas uznawanych za trywialne (wszelkie polityczne i ekonomiczne aktualia), więc wszystko, co jeszcze kilka lat temu uważano za synonim złego gustu i smaku, wymuszało na publiczności opowiedzenie się po jednej ze stron. Artyści wykorzystali zresztą ten fakt w jednym z głośniejszych swoich spektakli Byt sobie Andrzej Andrzej Andrzej i Andrzej, który stanowil fantazję na temat pogrzebu Andrzeja Wajdy, wymierzoną w polski establishment i tzw. kulturę wysoką. W jego strukturę twórcy wprowadzili fragmenty najbardziej krytycznych recenzji swoich przedstawień z podpisami ich autorów. Komentarze recenzentów wyświetlane na ekranie z jednej strony trafnie relacjonowały akcję sceniczną i działania aktorów, z drugiej były wyrazem ironicznego dystansu twórców do głosów nieprzychylnych ich teatrowi: pasowały do poszczególnych fragmentów przedstawienia, jednak niewiele mówiły o całości, pomijały jego problematykę i ideologię. Kompromitowały autorów tych opinii jako krytyków pozbawionych przenikliwości, którzy bez zrozumienia zatrzymują się jedynie na wizualnej warstwie inscenizacji.

Artyści chętnie polemizują z głosami krytykującymi ich twórczość albo społeczno-polityczne zaangażowanie. $Z$ reguły krytycznie odnoszą się również do mediów, chociaż nie unikają środków masowej komunikacji, doceniając ich przydatność w prezentowaniu swoich poglądów na szerszym forum. W pewnym sensie uczynili z mediów swojego sojusznika, chociaż nie próbują ich obłaskawiać, konsekwentnie stosując strategię artystycznego terroryzmu. Zdaniem Paula Virillo jest ona charakterystyczna dla sztuki w epoce zapośredniczonej komunikacji i wynika prawdopodobnie z bezradności wobec nadmiaru dostarczanych przez media bodźców i wrażeń:

Terroryzm nie jest wyłącznie zjawiskiem politycznym, także artystycznym. Mamy go w reklamie i w mediach, w reality shows, w pornografii medialnej. Ostatnia rzecz, jaką można uczynić, to zdzielić kogoś w twarz, żeby się obudził (Virillo 1997: 15).

Bezkompromisowość i dosadny sposób wyrażania poglądów okazują się skuteczne o tyle, że publiczne wypowiedzi duetu zwykle są później komentowane w Internecie. Chyba najbardziej spektakularnym przykładem była rozmowa z redaktorem Grzegorzem Chlastą na antenie radia TOK FM. Artyści zostali zaproszeni do studia w związku z ogólnopolskim protestem środowiska teatralnego w obronie teatru artystycznego „Teatr nie jest produktem/Widz nie jest klientem” (2012), którego byli inicjatorami. W odpowiedzi na prowokacyjne pytania dziennikarza zareagowali emocjonalnie, najpierw krytycznymi uwagami, później spektakularnym opuszczeniem studia. To zdarzenie nie uszło uwadze internautów, 
dziennikarzy i publicystów ([dżek] 2012). Przez kilka dni było szeroko komentowane, prowokując również do refleksji na temat społecznej roli mediów.

Rozumiejąc siłę i znaczenie mediów we współczesnym społeczeństwie spektaklu, Strzępka i Demirski wykorzystują ich potencjał również w procesie twórczym. Przygotowując się do prac nad spektaklem Tęczowa Trybuna 2012, który podejmował m.in. temat tolerancji wobec osób homoseksualnych oraz realnych możliwości tych grup do korzystania ze swobód i praw obywatelskich, przeprowadzili akcję społeczną. Założyli stronę internetową fałszywego gejowskiego fanklubu drużyny narodowej, www.teczowatrybuna2012.pl, który domagał się zorganizowania sektorów dla kibiców homoseksualnych na stadionach narodowych w trakcie Euro 2012. Strona była prowadzona przez pracowników Teatru Polskiego we Wrocławiu. Artyści skrzętnie ukrywali ten fakt, zaangażowali się natomiast $\mathrm{w}$ tworzenie mitologii nowego ruchu. W mediach opowiadali o spotkaniu $\mathrm{z}$ grupą gejów-kibiców z determinacją walczących o własne miejsca na stadionie narodowym, co okazało się bardzo inspirujące. Sprawa „Tęczowej Trybuny” została szybko przechwycona przez media (Ewa Siwek wynotowała ponad czterdzieści artykułów w Internecie na stronach polskich i ponad siedemdziesiąt na zagranicznych - Siwek 2011: 142-147), zaktywizowała kiboli warszawskich i krakowskich klubów sportowych, pojawiły się również pomysły włączenia do tych działań Kampanii Przeciw Homofobii, chociaż organizacja na początku była do pomysłu nastawiona sceptycznie. Projekt okazał się ciekawym eksperymentem społecznym, niestety nie wyszedł poza to, co wykreowali twórcy - działacze LGBT nie zdecydowali się na jego kontynuację. Pomysł z „Tęczową Trybuną” spowodował jednak sporo zamieszania i pod tym względem stał się inspirujący jako punkt wyjścia do powstania spektaklu. Dzięki niemu udało się również odsłonić polityczne oblicze sztuki w tym sensie, jak myśli o nim Jacques Rancière, dopatrując się polityczności w ustanawianiu widzialnym tego, co jest wykluczone, ujawnianiu mechanizmów społecznej opresji i obojętności, wreszcie wspieraniu walki o podmiotowość (Rancière 2007).

W przeciwieństwie do reżyserów, którzy po 1989 roku bardziej zainteresowali się indywidualnymi doświadczeniami człowieka w zmieniającej się rzeczywistości, Strzępka i Demirski śledzą to, co dzieje się w polityce i ekonomii. Z twórczością Klaty łączy ich zaglądanie pod podszewkę wspólnotowych mitów i tożsamościowych narracji. Podobnie jak Wiktor Rubin rozmontowują dominujące ideologie i dyskursy władzy. Jako pierwsi w swoim pokoleniu wprowadzili do teatru społeczne i polityczne aktualia, nadając teatrowi charakter publicystyczny. Mają nie tylko dużą świadomość mechanizmów rynkowych, lecz również wpływu mediów na życie społeczne i ich ogromnego udziału w projektowaniu relacji komunikacyjnych między wizerunkiem artysty a jego odbiorcą. Ta para to dzisiaj z całą pewnością wyrazista marka. Dzięki obecności w mediach coraz częściej rozpoznawalna nie tylko przez krytyków i wąskie grono teatromanów, ale również przez osoby, które rzadziej chodzą do teatru. Na obraz ich twórczości składają się nie tylko zaangażowane politycznie spektakle, które do teatru wprowadziły również nową jakość estetyczną, ale też akcje społeczne i wypowiedzi w massmediach, wreszcie założony podczas prac nad serialem Artyści punkowy zespół Czerwone Świnie, z którym koncertują po Polsce. Są wyrazistymi twarzami teatru politycznie zaangażowanego. Łączenie treści rozproszonych w różnych mediach i miejscach kultury pozwala rozumieć ich działalność teatralną i pozateatralną jako jedno przedsięwzięcie, zwłaszcza że medialny wizerunek trudno oddzielić od twórców, a i oni sami wskazują, że realizowane przez nich spektakle wynikają z prywatnych poglądów i doświadczeń. 


\section{Bibliografia}

[dżek] 2012. „Awantura u Chlasty. Strzępka i Demirski skrytykowali (prawie) wszystko i skrzyczeli prowadzącego". www.gazeta.pl 29.03.2012. http://wiadomosci.gazeta.pl/wiadomosci /1,114873,11447122,Awantura_u_Chlasty_Strzepka_i_Demirski_skrytykowali.html [20.08.2017].

Demirski, Paweł 2018. „Aktywizacja klasy średniej. Z Pawłem Demirskim rozmawiali Justyna Jaworska i Piotr Morawski”. Dialog 1. http://www.dialog-pismo.pl/rozmowy-dialogu/ aktywizacja-klasy-sredniej [20.04.2018].

Drewniak, Łukasz 2010. „Bonnie i Clyde, czyli teatralny blitzkrieg Strzępki i Demirskiego”. Przekrój 51.

Głowacka, Aneta 2015. „Teatr w mediach - media w teatrze. Medialność w spektaklach Moniki Strzępki i Pawła Demirskiego”. W: Artur Duda, Marzenna Wiśniewska, Barłomiej Oleszek (red). Teatr wśród mediów. Toruń: Wydawnictwo Naukowe UMK.

Krakowska, Joanna 2011. „Demi(d)ramy”. W: Paweł Demirski. Parafrazy. Warszawa: Wydawnictwo Krytyka Polityczna.

Papuczys, Jakub 2013. „Współczesny performans nie zna granic. Przykład Moniki Strzępki i Pawła Demirskiego". W: Ewa Bal, Wanda Świątkowska (red.). Performans, performatywność, performer. Próby definicji i analizy krytyczne. Kraków: Wydawnictwo Uniwersytetu Jagiellońskiego.

Rancière, Jacques 2007. Estetyka jako polityka. Tłum. Julian Kutyła, Paweł Mościcki. Warszawa: Wydawnictwo Krytyka Polityczna.

Siwek, Ewa 2011. „Klub Tęcza”. Notatnik Teatralny 64-65.

Strzępka, Monika 2011. „Był sobie Polak, Andrzej, czterej pancerni i gej. Z Moniką Strzępką rozmawiała Magdalena Grzebałkowska i Dorota Karaś”. Gazeta Wyborcza - Duży Format 03.03.2011. http://wyborcza.pl/duzyformat/1,127290,9195201,Byl_sobie_Polak Andrzej_czterej_pancerni_i_gej.html [20.08.2017].

Strzępka, Monika, Paweł Demirski 2008. „Dwie Polski i przepaść. Z Moniką Strzępką i Pawłem Demirskim rozmawiała Joanna Derkaczew". Gazeta Wyborcza 180 (02.08).

- 2011. „Teatr demokratycznej wspólnoty. Z Moniką Strzępką i Pawłem Demirskim rozmawiała Aneta Głowacka”. Program do spektaklu Położnice szpitala św. Zofii. Chorzów: Teatr Rozrywki.

Polityka2010(23.11).http://www.polityka.pl/tygodnikpolityka/kultura/paszporty/1510844,1,teatr-2010-nominowany-pawel-demirski-i-monika-strzepka.read [15.08.2017].

Virillo, Paul 1997. „Ślepe pole sztuki. Z Paulem Virillo rozmawiała Catherine David”. Tłum. Ewa Mikina. Magazyn Sztuki. http://magazynsztuki.eu/old/archiwum/nr_15/paul\%20virilio_david.htm [20.08.2017].

Węgrzyniak, Rafał 2008. „Teatr niezbyt angażujący”. Odra 6.

Wyznawcy 2008. „Z Moniką Fronczek, Agnieszką Przepiórką, Sabiną Tumidalską, Łukaszem Brzezińskim, Jerzym Gronowskim, Pawłem Wawerem rozmawiał Jan Czapliński”. Notatnik Teatralny 49-51. 